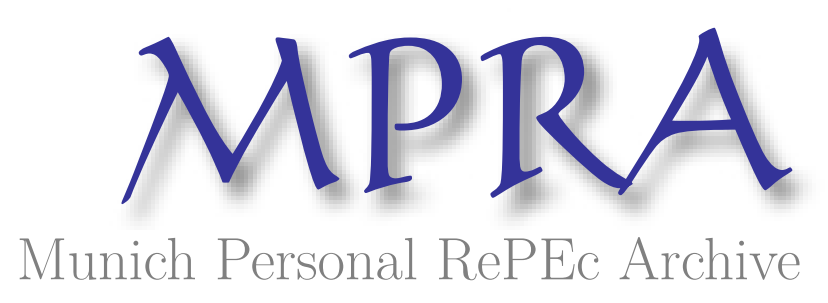

Europe of languages. Between the power of languages and the languages of power

Buda, Mariana

2014

Online at https://mpra.ub.uni-muenchen.de/63034/

MPRA Paper No. 63034, posted 23 Mar 2015 15:02 UTC 


\title{
Europe of languages. Between the power of languages and the languages of power
}

\author{
Mariana Buda \\ mariana.buda@yahoo.com
}

\begin{abstract}
$\underline{\text { Abstract }}$
In Europe, the languages are like water: mobiles and actives, shapeless and elastics, indispensables but without power. Even if they are subject of discussions between different forces, they are not governing the relations between States. So, one can ask himself the following question: our world of globalization is it going through linguistic unification or, on the contrary, fragmentation, or coagulation? In the more specific case of Europe, we can say that the languages are the bearers of dominated peoples. In what follows, we will dress the destiny of Europe of languages and the relationship between languages and power.
\end{abstract}

\section{Key words}

Languages of Europe, power of languages, European Union, English, multilingualism

\section{LANGUAGES OF POWERS}

\section{The Europe of the languages}

Languages exist in the world just as water exists on the planet: they are mobile and active, shapeless, yet elastic. Even if they are subjected to force reports, they do not govern the relations between states. This raises the following question: is our world on the way to a linguistic unification, or, on the contrary, in the course of division, or coagulation? In the particular case of Europe, we can say that languages are dominated peoples banners. ${ }^{1}$ In what follows, we will briefly present the destiny of Europe of the languages, presenting the languages that could have been a common language over time, as well as those that were self-imposed.

If we go back a few decades, we see a multitude of languages that existed and were used in the world. Clearly, in 1848 we were witnessing the creation of new countries over the ruins of the central empires. This is the case of the dismantling of the Soviet Union and Yugoslavia. However, many minds are still dominated by the nostalgic empire of a common language. It is a language that is able to meet the needs of the times and that is common to all Europeans. The multiplication of independent unilingual or multilingual states is beneficial. But at the same time, if we talk about the benefit - losses rapport, this resulted in an increase in the number of papers with the same content, especially in science and technology. Such a situation raises the desire for a common language to address economic concerns. Surely, the Western part of Europe has long held such a language: Latin. ${ }^{2}$

It is well known that Latin has long been the main pillar of Western Europe. However, the form that humanists assign Latin is the decline of the language. Because, when it is secluded in a rigid form, it becomes less apt to play modern ideas and the fluidity of scientific thinking. Chemists, naturalists and physicists had always need new words, phrases that were more flexible and more suitable for research,

${ }^{1}$ Ristikivi, Merike, Latin- The Common Legal Language of Europe? In Juridica International, 2005, p.199

${ }^{2}$ Hagège, Claude, Le soufflé de la langue, Voies et destins des parlers d'Europe, Ed. Odile Jacob, Paris, 2000 , p.16 
something that Latin did not offer. Since the mid-eighteenth century, Latin gradually ceased to be the language of correspondence between scientists. In the twentieth century, Latin completely loses its status and is no longer used. ${ }^{3}$

Later it is found that another European language, heir of Latin, appears as an intermediate language and manages to conquer vast territories. 1492 is the year of glory for Castilian. A. Nebrija, a great professor of Rhetoric at the University of Salamanca, wrote a famous inscription on one of his books: "Language has always accompanied power." ${ }^{4}$ The chorus reflects very well the spirit of the age. However, Spanish, Castilian language's recent appellation, has never been known in its history as the language of supranational communication in Europe. ${ }^{5}$

In places other than the Po Plain and its surroundings, Italian is also spoken in many forms, not only in mainland Italy, but also on the big islands, as well as in the Swiss canton of Ticino, in the Southern part of the one called Grison, in Istria and in other communities in various countries in Europe. The Latin origin of this language is evident in many aspects. Does this loyalty make Italian, the most direct heir of Latin, the founder of a common language in Europe ${ }^{6}$ It seems not, and it seems that we should consider other criteria if we want to know what might be the common language in Europe.

\section{Europe and the English language}

The destiny of the English language, as well as its strong diffusion in today's world, is carrying it to the antipodes. To assess its vocation as the common language in Europe, it is necessary to examine the sources of this destiny.

The first period of the English language history coincides with the Romanization of the province of Britannia and, later, with the advent of the Vikings. Old English, resulting from this cross of influences, is a language very well illustrated in the eighth century, through narrative, poetic and religious works. The second period, that of Middle English, began with the conquest of the country by Guillaume, Duke of Normandy, which imposes the Franco-Norman language as the official one. But the Englishspeaking bourgeoisie requires the imposition of English in legal documents. Later, English became the sole language of the courts and, in addition, in the late fourteenth century, French loses its place it occupies in education. Thus the third period of the language was inaugurated, that of modern English. ${ }^{7}$

Since the late eighteenth century, the destiny of English takes a new direction: it becomes the European language with the least influences, but the one that influences other languages the most. In addition, there was not in the tenth century a language that could be a bigger force for stability than English could. Thus constructed, English is seen by many as "simple", even though this concept does not make sense. But the simplicity assumed by the English language is not sufficient to explain its success in European countries, if another, more decisive factor is not added: colonial expansion. The result is what we can predict: Europeans see English as a language that best meets their essential need to communicate. ${ }^{8}$

\footnotetext{
${ }^{3}$ Ibidem, p.19

${ }^{4}$ Quoted in Kathryn A. Woolard and Bambi B. Schieffelin -Language Ideology, Annual Review of Anthropology 23 (1994), p. 67

${ }^{5}$ Becker, Carl J, A Modern Theory of Language Evolution, Ed. iUniverse, Lincoln, 2005, p.16-17

${ }^{6}$ Hagège, p. 29

${ }^{7}$ Becker, p.42-51

${ }^{8}$ Ristikivi, p.200
} 
Therefore, of all the languages in the world, English is the one evolving closest to people's needs, the first of which is to communicate. In addition, the American form of English is widespread in Europe through trade, arts and especially through the effects of economic and political power.

\section{The German language and its influences}

Germans, descendants of conquerors who probably lived in Jutland since the end of the second millennium, are mentioned late. However, because he chose to translate the Bible in 1534, in a Saxon dialect, which was his mother tongue, Luther set up unified written rules, which will become the modern German language. ${ }^{9}$

German then becomes the language of trade, communication and culture. Therefore, a German language that, in the tenth century, couldn't reach the Baltic Sea, managed, first in one of its forms and then another, by the action of the Hanseatic League and the Teutonic Knights, to be the dominant language in all the major cities on the Southern Baltic coast and part of Central Europe. It will remain so even later, during Russian domination.

Since the late 30 s, the European vocation of the German language ${ }^{10}$ pulsed in a turbulent history, has experienced a serious decline following the Second World War and the Nazi violence. Today, German does not seem exposed, especially if the political and social circumstances remain as they are. In addition, German has already begun being beneficial. In March 1992, the Czech Minister of Education insisted that the German language replace English as the compulsory language for the baccalaureate, more proof that power and language go hand in hand.

\section{French language and its multilateral vocation}

The European vocation of the French language is ancient. It feeds on the radiant period that remains attached to the national memory. These are two eras in particular, quite distant from one another, in which French language shone in Europe. One is between the twelfth and thirteenth centuries, and the other between the second half of the seventeenth century until the eighteenth century. Both can be explained quite well by the blend of political, military, social and cultural causes, normally serving to illustrate the language beyond its borders. ${ }^{11}$

Without going into details, it is known that the French language was among the first European languages, which, in addition to a national authority and based on a political unit, was assigned with the written language status. English, Spanish, Portuguese, Polish, which also had this status, have not experienced the same broadcasting in Europe.

The periods we talked about above have shaped in the national consciousness an image of the vocation of a reference language. The first period begins with the conquest of England by William of Normandy. At this time, the domination of the French language starts, which will last more than three hundred years. Even foreign scholars as Latini or Da Canale and students from the University of Paris,

\footnotetext{
9 Andrean, Linda, A brief History of the German Language, The Language of Austria, Germany, and Parts of Switzerland, Center for Austrian Studies, University of Minnesota; http://www.cas.umn.edu/assets/pdf/GermanLanguage.pdf

${ }^{10}$ Hagège, p.90-92

${ }^{11}$ Ibidem, p.95-97
} 
emphasized in that period the prestige and the wide dissemination of the French language, calling it "the most agreeable upon and the most common language of all people." ${ }^{12}$

However, in the fourteenth century, the French language reaches a disadvantage. There are two reasons for this: firstly, the adoption of English by the Parliament and the Royal Government in London and secondly, the crisis of feudalism and the rising of the national bourgeoisie, which imposed its own language and culture.

The same thing happens in the second period of French domination. Just like in the Middle Ages, we see here the effect of three important factors: the war fortunes, on the one hand, political success, on the other hand, and, finally, the quality of great authors' works. In other words, the image of the French language was already that of a language of the elite and privileged classes. English did not have this connotation, since, on the contrary, its popular vocation was fueled by the fact that it was in England during the Norman monarchy the language of the masses. To this different image, a phenomenon announcing a new decline is added: the disastrous Treaty of Paris in 1763, depriving France of the Canadian territory, the Ohio Valley and the left bank of the Mississippi River. The ultimate consequences of this episode are the ones we see today laid across the Atlantic, on both its sides, both the English and American ones: English already had all the elements to become the language of the world center of business and relations between the most powerful two continents. ${ }^{13}$

However, a third period of French glow can be located in the extension of the second. It is France's colonial experience and with this, we can mention the dissemination of French through an open school policy to the colonial world, as well as the rest of the world. What ended it, are probably two factors: firstly, the political and military decline of France and secondly, the disappearance of the colonial empires.

The three dominant oriented languages that we talked about above are rightly considered the pillars of Europe. But they are just three of a big number. Europe is based on a very diverse and complex linguistic world. The contingencies of history had combined their effects with the constraints of geography. This can be a cause of the restless fate of Europe. If we ask ourselves where this Europe of the languages ends, we could simply reply: diversity resisted the impulses of identity! Europe of the languages has its own destiny and it is not known to be inspired by foreign models. ${ }^{14}$ If the adoption of a single language has emerged in the United States for any new immigrant as a seal of identity, making Europe original is precisely the diversity of languages and cultures. The dominance of a single language such as English, for example, would not correspond to this destiny. It would just answer the need for a permanent opening. In fact, Europe has not only searched for one language, having always been aware of the importance of diversity, but it always wanted a simple and common means of communication for everyone. Therefore, Europeans will have to raise their children in a variety of languages and not in unity. This is both the answer of the past and of the future.

\section{THE POWER OF LANGUAGES}

\section{Cultural languages and working languages}

\footnotetext{
${ }^{12}$ Becker, p.100

${ }^{13}$ Hagège, p.109-114

${ }^{14}$ Burke, Peter, Languages and Communities in Early Modern Europe, Cambridge, 2004, p.15-25
} 
Now, after we have seen the journey of the major languages in Europe and the reason for this journey explained by historical facts, we believe it would be useful to see another distinction of languages. Heinz Wismann, philosopher, philologist, director of studies at the "Ecole des Hautes Etudes en Sciences Sociales" (School of Higher Studies in Social Sciences), director of the collection "Passages" of the "Cerf de France" Publishing House, makes an important and interesting distinction between "cultural languages" and "working languages". He starts with the premise that the first one takes into account the historical dimension of a language, while the latter operates only in the present, meaning that the language is only used as a means of communication. The danger is, however, that reducing language to a simple communication tool makes it a mere working organism. In the following, we will argue the distinction he makes.

Heinz Wismann states that working languages and cultural languages are not different languages, but different uses of a single language. Any language can, in a certain context, function as a working language. Working languages are characterized by an assumption that radically separates them from cultural languages, that the universe that such a language refers to preexists the language use. It is therefore the assumption of a common world, a world to which all interlocutors must refer to without worrying that they are not understood. In this respect, working languages are truly servile and useful. They are of great use in situations that we can enumerate. However, this usage of the language would not allow a real dialogue between individuals, because a dialogue requires everyone to be able to say exactly what they keep inside them and to pass their discourse through themselves. ${ }^{15}$

Unlike the use of language as a working language, cultural languages appeal to the past of a language that is the intrinsic part of any living language. A cultural language appeals to the past in order to reactivate it, to extrapolate something that still was not said. What makes this operation valid or acceptable is that it meets a set of rules that are exactly the rules of grammar in the broad sense of a cultural language. Working languages cannot only ignore a complex vocabulary, but they can also simplify grammar to the extreme, because in a denotative system, we do not need a complicated syntax, difficult times, or subordinates. ${ }^{16}$

Therefore, we have to distinguish between the two usages of a language. If the cultural usage is an inventive one, inseparable from grammar and history, the working usage only operates in the present. Therefore, learning a language should be made taking into account historical and cultural dimensions of that said language. Otherwise, we may not really know the language, but only a part used to communicate.

Regarding French Language, Heinz Wismann believes that "French can exist as a cultural language only if the historical dimension is present in its learning. ${ }^{17}$ In fact, this is true for all the languages. The threat looms to French as a cultural language, German as a cultural language, English as a cultural language, etc. And if it is true that a cultural language cannot survive without the historical perspective present in its learning, there is an essential condition for languages to last, namely that they must be renewed and refreshed. A language that remains in an invariant state is already in decline. Therefore, all languages, especially English, are in danger of being reduced to their working usage.

\footnotetext{
${ }^{15}$ La langue française dans la mondialisation in the on line publication: « Le Débat », numéro 136, septembreoctobre 2005/4, Dossier, Editions Gallimard : http://le-debat.gallimard.fr/dossier_revue/langue-fran-aise-dans-lamondialisation/

${ }^{16}$ Ibidem

${ }^{17}$ Ibidem
} 
However, it is true that the European institutions use some language as working languages, but this is a topic we will talk about another time.

Currently, we can see a widespread use of English as the working language in many areas of life. Can we ask ourselves why English and not another language? The answer is that the English language bends itself more easily than any other European language and, therefore, there is a strong predisposition to work in English, more than any other language, as the working language. However, we have to see both sides of the English language: de-grammaticalization, representing a propensity toward a working language and idiomatization, making English a difficult language to be practiced if we want to learn it as a cultural language.

\section{Multilingualism in the European context}

Surely, languages do not obey the laws of economics or biology. They do not go through a youth, maturity and old age as their nations. They act as independent and undetermined organisms. If they live, they are as a culture or as a means of media, powered by an external energy, inspired by the human spirit. This is the reason why, in the European Union, multilingualism has been chosen as the expression of multiculturalism. It is a cultural choice. The languages we speak must be kept, no matter how numerous they may be, because they are part of our cultural heritage.

To those who defend it, multilingualism is perceived as a solution to the disappearance of several languages. This problem threatens the cultural diversity of the planet, providing for the disappearance of a number of major languages which consist of so many different ways to see, understand, classify and determine the relations between things. Indeed, we know that $90 \%$ of languages are endangered, because they could disappear in 50 years from now. ${ }^{18}$

The European Union has as an official objective multilingualism. EU language policy provides for the use of languages in the European institutions, but also promoting their teaching, and therefore assigning symbolic recognition to each language spoken in the EU. Meanwhile, multilingualism is one of the main problems that the European Union focuses on. In an area in which we find 28 different nations, more than 500 million people, we have 24 official languages and several regional languages recognized by the states in which they are spoken.

The treaties and decrees of the European Union try to keep the cultural and linguistic identity of each country. Meanwhile, the European Union gives every citizen the right to appeal a European institution in their own language and, moreover, to be answered in the same language. ${ }^{19}$ However, in practice things are not the same as in theory, mainly due to recent additional members to the European Union. For several years, institutions are preparing for this unprecedented linguistic challenge. Between monolingualism and multilingualism in full, several scenarios are possible for the Union to win this wager of multilingualism.

The problem of languages has always been sensitive within the EU and that is because the orders of magnitude are considerable. For example, when assessing the amount of paper used each month by the Commission to translate all documents, it would reach almost half of Luxembourg! Regarding the acquis

\footnotetext{
${ }^{18}$ Les européens et leurs langues in Eurobaromètre 386, p.5-8: http://ec.europa.eu/public_opinion/archives/ebs/ebs 386 fr.pdf ${ }^{19}$ Official site of European Parliament: http://www.europarl.europa.eu/aboutparliament/en/007e69770f/Multilingualism.html
} 
communautaire that each of the Member States has to translate at its own expense, it alone represents nearly 100,000 pages. ${ }^{20}$

Therefore, the status quo is no longer viable due to the large number of official languages and existing budget constraints. Equality between the official languages of the Member States is a fundamental principle of the European Union. Initially, in the 1950s, this principle was simple to apply: the Union constituted six countries representing four languages (French, German, Italian and Dutch). In 1973, with the United Kingdom, Ireland and Denmark, two languages were added. By 1995, there were eleven official and working languages. With the expansion in 2004, ten new languages are added. In 2007, when Romania and Bulgaria joined the EU, there already were 23 official and working languages, for the year 2013 to bring another language within the EU - Croatian.

So even if it is difficult or sometimes impossible, the European Union does not abandon the idea of promoting linguistic pluralism and cultural diversity. Moreover, in addition to the EU, multilingualism is applied in key international organizations such as the UN, OECD, WTO, NATO, UNESCO, OSCE, etc.

The United Nations recognizes six official languages: English, French, Spanish, Russian, Chinese and Arabic. We underline, as a brand of history, that German does not have official status. The organization works in two working languages that are English and French. But in practice it tends to use English more. Faced with this situation, and in response to the increasing pressure, a report promoting multilingualism in the United Nations was presented by the Secretary General of the United Nations. This document encourages the provision of language training to the personnel, reliance on the use of both working languages equally, the release of documents once they are available in both working languages, limiting informal meetings without translation and a better balance in the provision of language documentation services and databases. ${ }^{21}$

On the occasion of the fiftieth anniversary of the signing of the Charter of the United Nations, the General Assembly adopted Resolution 50/11 on multilingualism, dated November 2, 1995, in which it stressed that "the universality of the United Nations and its corollary, multilingualism, implies that each Member State of the Organization, regardless of its official language, has the right and duty to make itself understood and to understand others." The Assembly also stressed the importance of ensuring access for all the governments and all the sectors of civil society to the documentation, archives and databases in all the official languages of the Organization. It requested the Secretary General to ensure strict implementation of the resolutions establishing the languages, both in the official languages and in the working languages of the Secretariat and invited Member States to do the same. Following the suggestion of the WHO and UN secretariats of the United Nations, the report on multilingualism has been included in the work program of the unit. ${ }^{22}$

UNESCO, recognizes six official languages (Arabic, Chinese, Spanish, French and Russian), and two working languages used daily by the Secretariat, which are English and French. This requires a good knowledge of both languages by UNESCO staff. In 2000-2001, the cost of interpretation in the six official languages was of 5 million Euros. In the Executive Council, composed of 58 Member States (a branch of the General Conference, which meets four sessions biennially), about $20 \%$ of the interventions

\footnotetext{
${ }^{20}$ Compte-rendu 48 in Délégation pour l'Union Européenne, p. 2 in http://www.assemblee-nationale.fr/12/pdf/europe/c-rendus/c0048.pdf

${ }^{21}$ Rapport d'information sur la diversité linguistique dans l'Union Européenne, p. 28 in http://www.assemblee-nationale.fr/12/europe/rap-info/i0902.asp

${ }^{22}$ Ibidem, p.29
} 
are conducted in French. We can mention a referral of the Director General of UNESCO, on 17 October 2002, which stated the mandatory requirement of proficiency in both languages, because "in order to improve the recruitment process, a candidate from a non or under-represented state with an advanced knowledge of one of the working languages should make the short list. If hired, the candidate will need to acquire a reasonable knowledge of the second language through a mandatory training program." Using only one of the two working languages as a condition for the UNESCO recruitment program is a worrying sign for the decreasing use of French in the organization. ${ }^{23}$

In the OECD, we find two working languages: English and French, which are the official languages and working languages at the same time. In practice, we observe a strong imbalance in favor of English. In the WTO, there are three official languages: English, French and Spanish (added in 1979). The category of "working languages" does not exist in the WTO: English is the de facto used systematically; it is the language of about $90 \%$ of documents. Regarding NATO, English is the used language. French is used in very rare summits. ${ }^{24}$

However, to demonstrate the importance of multilingualism, the European Union designated 2008 as "the European Year of Intercultural Dialogue". Multilingualism has an essential role and its contribution is essential for carrying out this rally. The European Union took several measures to promote multilingualism, but also encountered many difficulties. In fact, it is about the language policy pursued by the European Union regarding a subject as important as multilingualism.

\section{References}

- Andrean, Linda, A brief History of the German Language, The Language of Austria, Germany, and Parts of Switzerland, Center for Austrian Studies, University of Minnesota; http://www.cas.umn.edu/assets/pdf/GermanLanguage.pdf

- Becker, Carl J, A Modern Theory of Language Evolution, Ed. iUniverse, Lincoln, 2005

- Burke, Peter, Languages and Communities in Early Modern Europe, Cambridge, 2004

- Compte-rendu 48 in Délégation pour l'Union Européenne in http://www.assembleenationale.fr/12/europe/c-rendus/c0048.asp

- Hagège, Claude, Le soufflé de la langue, Voies et destins des parlers d'Europe, Ed. Odile Jacob, Paris, 2000

- La langue française dans la mondialisation in the on line publication: «Le Débat », numéro 136, septembre-octobre 2005/4, Dossier, Editions Gallimard : http://ledebat.gallimard.fr/dossier revue/langue-fran-aise-dans-la-mondialisation/

- Les européens et leurs langues in Eurobaromètre 386, http://ec.europa.eu/public_opinion/archives/ebs/ebs_386_fr.pdf

- Official site of European Parliament: http://www.europarl.europa.eu/aboutparliament/en/007e69770f/Multilingualism.html

- Rapport d'information sur la diversité linguistique dans l'Union Européenne, in http://www.assemblee-nationale.fr/12/europe/rap-info/i0902.asp

- Ristikivi, Merike, Latin- The Common Legal Language of Europe? In Juridica International, 2005

- Woolard, Kathryn A., Schieffelin, Bambi B. -Language Ideology, Annual Review of Anthropology 23, 1994

\footnotetext{
${ }^{23}$ Ibidem, p.30

${ }^{24}$ Ibidem, p.31
} 